\title{
Analysis of Chinese Economic and National Security Interests in China- Pakistan Economic Corridor (CPEC) under the Framework of One Belt One Road (OBOR) Initiative
}

\section{Saif Ur Rahman* and Zhao Shurong}

School of Political Science and Public Administration, University of Electronic Science and Technology of China, China

"Corresponding author: Rahman SU, School of Political Science and Public Administration, University of Electronic Science and Technology of China, China, Tel: +8615528125980, 862861831756; E-mail: rehman107@yahoo.com

Received date: June 06, 2017; Accepted date: July 13, 2017; Published date: July 19, 2017

Copyright: (c) 2017 Rahman SU, et al. This is an open-access article distributed under the terms of the Creative Commons Attribution License, which permits unrestricted use, distribution, and reproduction in any medium, provided the original author and source are credited.

\begin{abstract}
The China-Pakistan Economic Corridor (CPEC) is a lead project of "One Belt One Road (OBOR) Initiative" formally announced in April 2015. The multibillion US Dollar project of CPEC offers much needed avenues of economic growth and political stability for Pakistan and the region at large. Much is known about the promises which the project offers to Pakistan, however, very little academic discussion is found on the aspects that what benefits China will accrue being the financer of the project. Therefore, this paper is an attempt to analyze Chinese economic and geo-strategic objectives from the CPEC, carrying out discussions under the broader framework of OBOR Initiative. The study uses qualitative methods of investigations to find out some of the very important Chinese ambitions from the Belts and Roads Initiative. The project is the practical manifestation of the Chinese vision of "Peaceful Rise" and regional integration which is expected to usher a win-win situation for the partnering countries. The paper concludes that if the perceived objectives are attained, it will prove to be a "game changer" for the region and World at large, marking a new era of World Development led by China.
\end{abstract}

Keywords: China-Pakistan economic corridor; One belt one road initiative; Chinese economic interests; Chinese national security objectives

\section{Introduction}

One Belt One Road (OBOR) Initiative is the grand strategy of China to connect Eurasia, South East Asia, South Asia and Africa through roads, railway lines, maritime routes and energy infrastructure. An HSBC research report shows countries along the OBOR account for $64 \%$ of the global population and $29 \%$ of the World GDP [1]. The OBOR has two components, namely, the land based "Silk Road Economic Belt" and Oceangoing "21st century Maritime Silk Road". CPEC is part of the land based component of OBOR Strategy. Since it was formally launched by Chinese President Xi Jinping in April 2015, CPEC is being termed as a "game changer" by many analysts worldwide. It is a 46 Billion US Dollar project connecting Xinjiang Province in Western China to the Gwadar Port city in Southern Pakistan through a network of communication and energy infrastructure covering a distance of 3000 kilometers, passing through the Khunjerab Pass in Northern Pakistan [2]. The project is envisaged to be completed in 2030 with construction of Gwadar Port, multiple Economic Zones, railway lines, Energy Projects, fiber optics for communication and Gwadar City airport (Figure 1) [3].

\section{Pakistan's share in the development}

CPEC offers a ray of hope for Pakistan, which has remained in the grip of poor economic growth, energy crisis; terrorism and deteriorating law and order situation since it joined the US led War in Afghanistan after 9/11. The project offers avenues of unprecedented economic growth and prosperity for Pakistan.

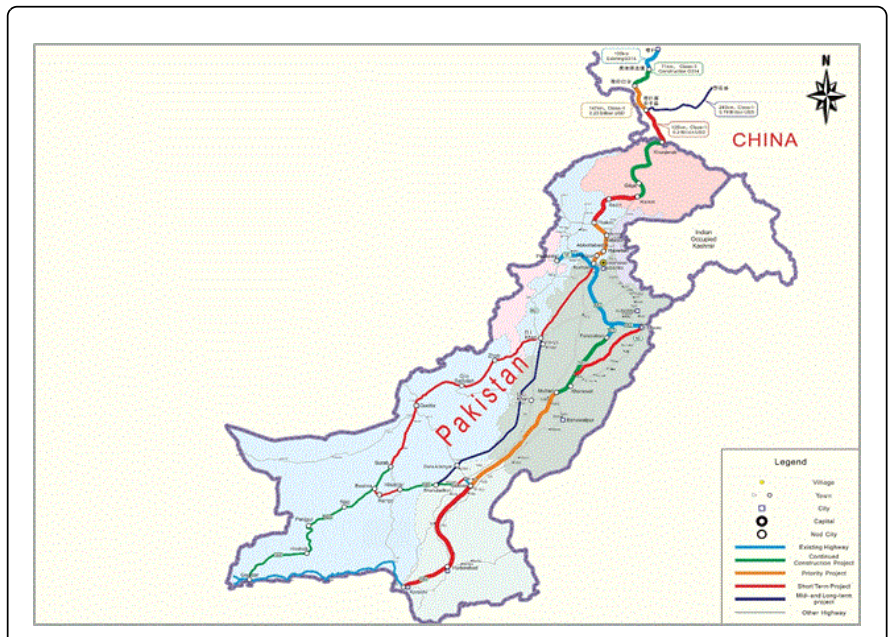

Figure 1: Routes of CPEC in Pakistan, (Source: Government of Pakistan).

As the statistics released by the Indian Council of World Affairs show, CPEC aims to add 17,000 megawatt of electricity to the national grid of Pakistan with an investment worth \$34 billion. Other investments of around $\$ 4$ billion dollars each is committed to the sectors of high-speed railways and the motorway network from Gwadar to the Khunjerab pass in northern Pakistan linking it with China. The Remaining amount out of the initial \$ 46 billion dollar project would be invested in development of Gwadar Port/city, establishment of special economic zones and laying fiber optic cable between the two countries [4]. The Sectoral distribution of invested 


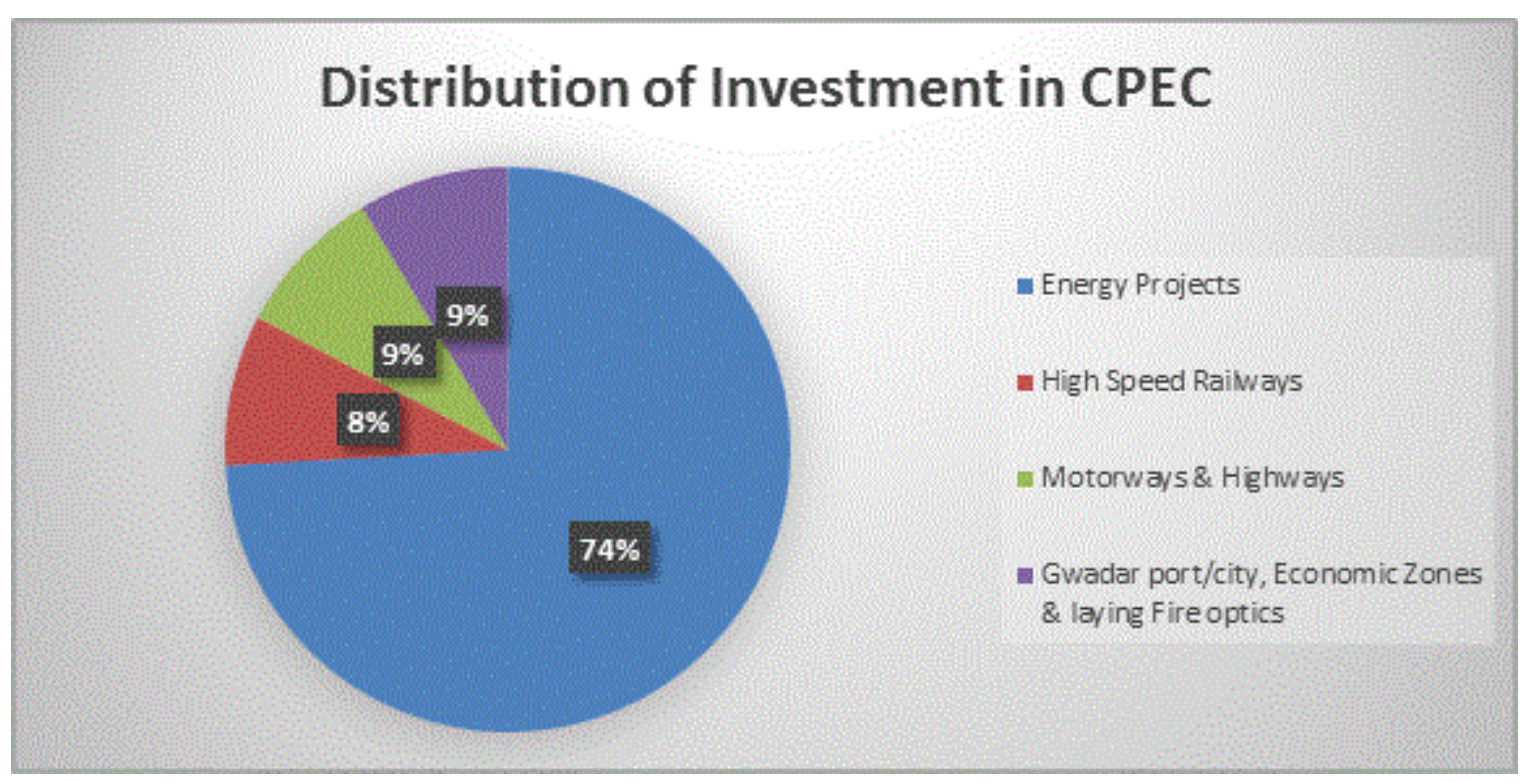

Figure 2: Sectoral Distribution of initial CPEC investment, (Source: Report of Indian Council of World Affairs).

\section{Chinese grand strategy of sustained economic growth}

CPEC is essentially an economic undertaking, which may have geopolitical implications in the long run. The OBOR Initiative in the broader scope is a strategy for the utilization of Chinese excess capital and industrial output. The Chinese leadership has openly acknowledged that the excessive Industrial and Capital output in 1930's Europe precipitated the initiation of World War-II [6]. The rapid industrialization in Japan and Europe in the later part of nineteenth century also gave a rise to conflicts among competing nations in the race for resources while utilizing their excessive economic output potential.

When a nation reaches excessive output potential, where it cannot find any further markets for its surplus productivity, its economy enters into a phase of stagnation. It faces a dilemma either to opt for a slow decaying process or find new avenues for utilization of surplus economic potential. The option of converting the excessive output potential into military might and generating means of economic growth were the model followed by the great powers in the late nineteenth and early twentieth century.

Due to rapid industrialization after World War-II, Japan was also considered a threat to US financial hegemony in 1980s and it was considered that soon it would overtake US as World's biggest economy. But, thereafter, since 1980, its economy has stagnated. It could not find consumption for its excessive industrial output. After the Asian Financial Crisis of 1997, Japan moved to establish the Asian stabilization Fund, only to be vetoed by the United States. Japan could not beat the US financial system as it could not move away from the Breton wood Institutions, where US has a monopoly. China has devised its own strategy of sustaining economic development by investing in developing countries of Asia and Africa. The forming of
New Development Bank, Asian Infrastructure Investment Bank (AIIB) and the Silk Road Fund are the steps in those directions.

\section{Economic Prospects of CPEC for China}

The One Belt One Road Initiative is estimated to have an investment of \$4-8 trillion covering about two third of World's land mass in 65 countries having a population of 4.4 billion people [7]. Other land based pillars of OBOR include the China-Mongolia-Russia Economic Corridor (CMREC), Bangladesh-China-India-Myanmar Economic corridor (BCIMEC), China-Indochina Peninsula Economic Corridor (CIPEC), China-Central and West Asia Economic corridor (CCWAEC) and the new Eurasian Land Bridge (NELB). It aims to connect East Asia, South Asia, Central and West Asia and Europe from the Malay Peninsula to the Mediterian Sea by constructing high-speed railways, highways, ports, economic zones and industrial areas.

Around 50,000 miles of high-speed railways are planned to be built under the initiative, more than the existing in whole World [7]. In spite of serious security and governance challenges in Pakistan, the ChinaPakistan Economic Corridor (CPEC) has been selected as the leading project under this initiative, which affirms Chinese commitment to Pakistan and the strong relations between the two countries. Some of the Chinese perceived outcomes from the project are discussed in succeeding paragraphs (Figure 3) [8].

\section{Prospects for Chinese Economic Growth}

Since its "opening up" to the World in late 1970's, China has experienced an unprecedented economic and social development. It maintained an average nearly 10 percent GDP growth for the past thirty years, which is the fastest sustained expansion by a major economy in the history [9]. Since 2012, the Chinese economy is slowing down gradually, which is a worrisome factor for the leaders in 
Citation: Rahman SU, Shurong Z (2017) Analysis of Chinese Economic and National Security Interests in China-Pakistan Economic Corridor (CPEC) under the Framework of One Belt One Road (OBOR) Initiative. Arts Social Sci J 8: 284. doi:10.4172/2151-6200.1000284

Page 3 of 7

Beijing. Annual growth target in the 12th five year plan was 7 percent which has been lowered to 6.5 percent in the 13th five year plan (2016-2020). China is the second biggest economy of the World; however, its per capita income is still a fraction of advanced countries.

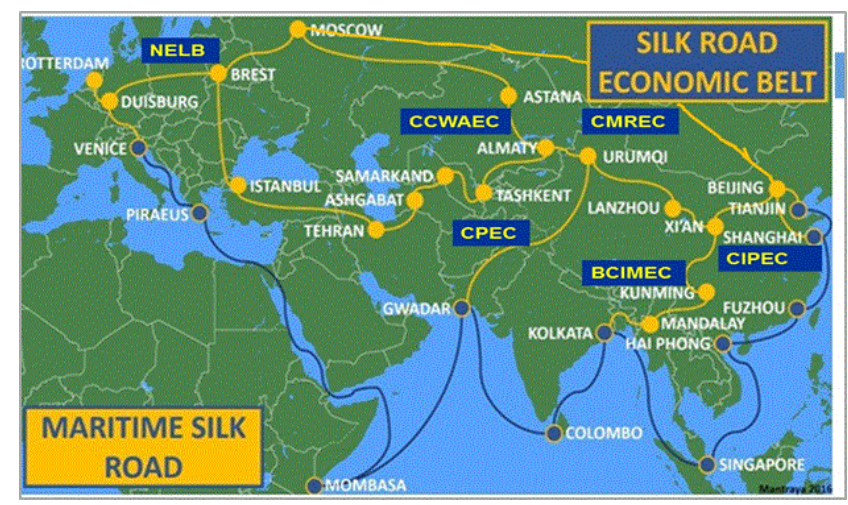

Figure 3: Routes of OBOR Initiative, (Source: Eurasia Review).

Economic analysts believe that transition from middle-income to high-income status can be more challenging than moving up from lower income to middle income. The developed economies have no more potential for expansion; therefore, the investment by Chinese companies in CPEC projects would bring a sustainable economic growth for China, employment for highly skilled workforce and consumption for the Chinese manufactured goods and services. Chinese companies can benefit from the cheap labor in Pakistan, where two thirds of the population is under the age of 25 years, while retaining opportunities of highly skilled job markets to the Chinese nationals.

\section{CPEC will open China to the Indian Ocean and Middle East}

The Middle East represents 50\% of the world's oil reserves and 25\% of global oil production. Middle East oil became a core national security issue for the USA after 1970's oil crisis. The Jimmy Carter administration in 1980, declared that, "An attempt by any outside force to gain control of the Persian Gulf region will be regarded as an assault on the vital interests of the United States of America, and such an assault will be repelled by any means necessary, including military force", known as Carter Doctrine [10]. According to a Forbes report dated Apr 20, 2016, US dependence on foreign oil has hit a 30-year low. Oil imports from Middle East are decreasing due to rising domestic oil shale exploration and shifting to the use of coal [11]. With rising oil consumption, China is likely to be a key stake holder in the of the Middle East oil and Gwadar Port, the World largest deep sea port located just 250 kilometers from the Persian Gulf will turn out to be strategic outpost for future Chinese interests in the region.

The project of CPEC would connect the Western Chinese province of Xinjiang with Gwadar port in Indian Ocean through an oil and gas pipeline along with a planned high-speed railways and highway network. China imports nearly $52 \%$ of its oil supplies from the Middle East and due to increasing domestic exploration by America; USA is forecast to be a net energy exporter by 2026. As the statistics released by the World Top Exporters for the year 2015 show, China imported \$
69 billion from Middle East out of its total oil imports worth $\$ 134.3$ billion dollars (Figure 4) [12].

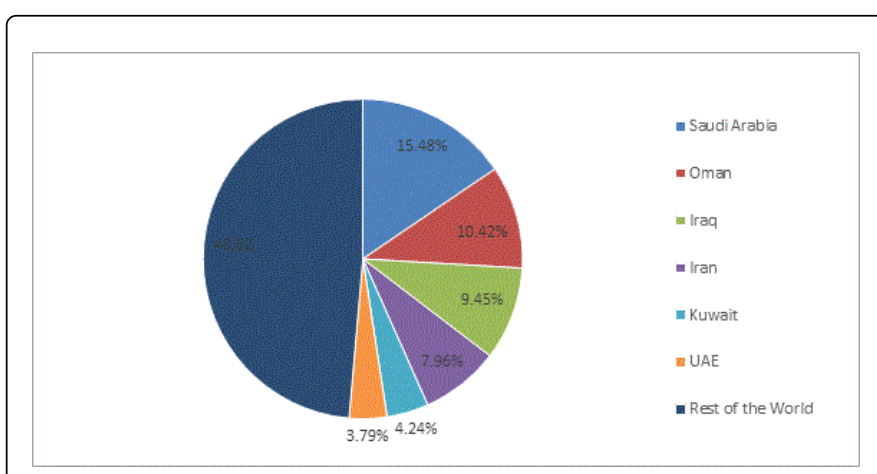

Figure 4: Chinese oil imports, (Source: World's Top Exports).

The distance for Middle East oil supplies to China would be shortened to a 3000 kilometers overland road as compared to the existing 12000 kilometers by sea. Research studies show that the CPEC is cost effective, causes less Green House Gases (GHG) emission and takes shorter time in transporting energy supplies to China as compared to BCIMEC. CPEC would provide the shortest time frame of just 6 days for the energy supplies to reach Chinese border through a pipeline as compared to 32 days via the current marine route and 19 days via proposed BCIMEC (Figure 5) [13].

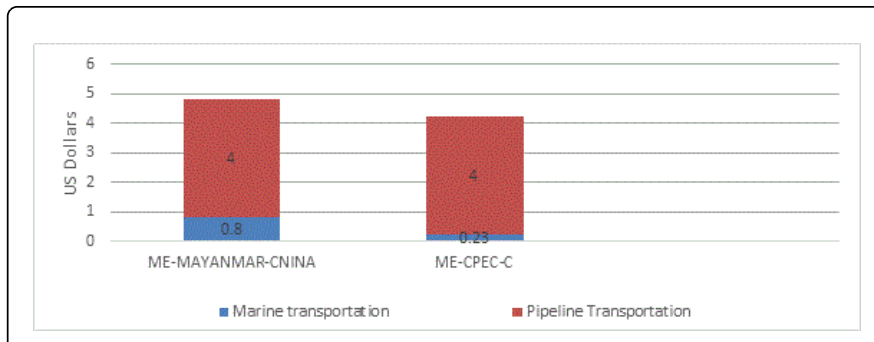

Figure 5: Per barrel transportation cost of Middle East oil Through CPEC and BCIMEC, (Source: Renewable and Sustainable Energy Review).

\section{Opportunity for Consumption of Surplus Output Potential}

China has faced a chronic problem of excess capacity since 2009. The four industries with severe excess capacity are Steel, Cement, flat glass and aluminum. According to the steel wire, in 2015 China produced 805 million tons of steel, more than the combined production of rest of the World. The chart shows that China's steel accounts for more than twice the combined output of the next four biggest steel markets in the World: Japan, India, US and Russia (Figure 6) $[14]$.

In just two years of 2011-12, China produced as much cement as US did during the entire 20th century [14]. The main factors of this surplus capacity are the domestic investment driven growth model, market saturation and the stimulus programs implemented after 2008 financial crises. This massive and rapid investment growth has built up significant capacity in manufacturing, construction and transportation industries. Due to the magnitude of Chinese export, the excess 
capacity is also causing rift between the Chinese Exporters and local companies in foreign countries. From 1995 to 2015, China ranked at top among the countries against whom anti-dumping and countervailing measures were taken abroad [15].

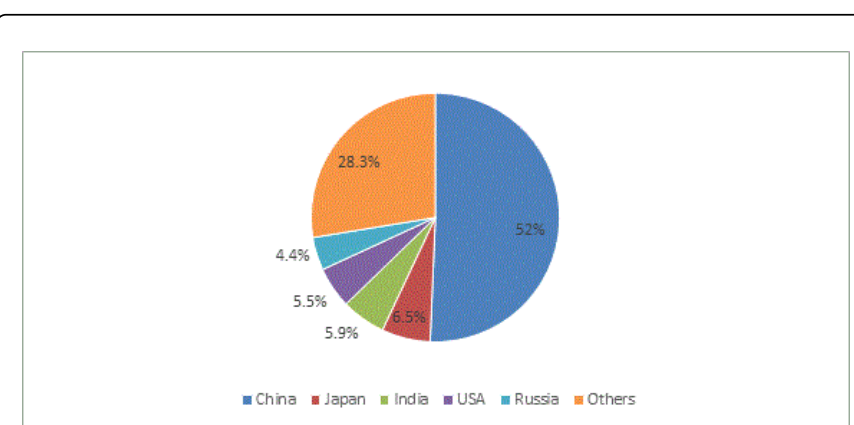

Figure 6: Percentage share of global steel production, (Source: Steel Wire).

The overcapacity is also impacting negatively on Chinese economy as the firms are faced with low demand, low profits and even the danger of bankruptcy. Therefore, a series of measures have been taken to tackle the excess capacity problem at home and abroad by the Chinese government.

Construction of Highways, railways, economic zones and energy projects by Chinese Companies as part of the CPEC would contribute quite significantly to the over capacity problem in the critical sectors and generate positive economic indicators for China. As the 2016 statistics showed, Pakistan had a demand of 7 million tons of steel against production capacity of 4 million tons [16]. Formation of $\$ 40$ billion dollar Silk Route Fund, \$ 100 Billion dollar AIIB, and the OBOR Initiate will utilize the excessive financial and Industrial capital and generate economic opportunities for China in the long run [15].

\section{Readjustment in the Chinese Economic Growth Model}

Readjustment in its economic growth model is considered to be another objective of China in the manifestation OBOR Initiative. The old model of export oriented manufacturing, cheap labor and domestic investment driven economic growth is no more applicable and China needs to find a new strategy to sustain its economic growth. CPEC in the broader perspective of OBOR Initiative is a component of Chinese new strategy of shifting from domestic investment model to the model of economic growth led by investments outside China. HSBC reported that, in 2014 China's Outward Direct Investment (ODI) exceeded to the Foreign Direct Investment (FDI) it attracted for the first time [1]. China is leading the World in its high-speed railway system and infrastructure development as it is equipped with both capital as well as knowledge to put across the World. Chinese companies are involved in constructing energy projects worth $\$ 33$ billion as part of the CPEC to be completed in 2017-18 [13]. Pakistan as the early beneficiary of the OBOR Initiative will be a bench mark for the success of this strategic initiative as well as the new economic growth model involving developing countries.

\section{Internationalization of the Renminbi (RMB)}

Since the OBOR Initiative covers two third of World's land mass and huge population, the rise of $\mathrm{RMB}$ as an international currency is inevitable especially in countries along the OBOR Initiative. The survey conducted by Bank of China (BoC) reflected that $80 \%$ of the Belt and Road respondents were planning to increase their use of RMB in the future [17]. Nearly $60 \%$ of the Chinese ODI is being denominated in RMB compared to $16 \%$ in 2013. Internationalization of RMB is likely to rise in future, as the financial Institutions involved in providing $\$ 1.8$ trillion dollar credits to the OBOR Projects will finance a major chunk in RMB. The use of RMB as a regional currency in South Asia will rise as the major portion of Infrastructure development in CPEC is being implemented by Chinese companies. The BoC report also concluded that some neighboring countries will add RMB to their reserve currency basket as well [17]. The project will enhance multilateral currency cooperation; more direct trading in $\mathrm{RMB}$ and currency swap agreements in the region will boost the use of $\mathrm{RMB}$ in the region. So far the China Banking Regulatory Commission (CBRC) has signed currency swap agreements with Russia, Mongolia, Kazakhstan and Uzbekistan amongst its neighbors.

People's Bank of China has also stated that it would encourage cross-border currency lending and investments to support OBOR strategy. Bank of China (BoC) is already pushing forward its drive for internationalization of RMB through issuance of four currency (US Dollar, Euro, Singapore Dollar and RMB) bonds since 2015 to support OBOR Initiative. The project will increase Chinese experiences in operating RMB as an international currency and would be a step towards a long term goal of making it an international reserve currency [18].

\section{Opportunity of Development for the Western Chinese Provinces}

One of the complements of CPEC is that it will facilitate economic development of western provinces of China. The four decades of export oriented economic boom has left huge economic disparity between western and eastern provinces, because, major industries were set up in the coastal cities of the east to facilitate the exports. As per the reports of 2013, the per capita income difference among western provinces of Xinjiang, Gansu, Guizhou and Qinghai were one third to half of the per capita income of the eastern provinces of Guangdong, Fujian and Zhejiang. As of 2015, it was estimated that the western provinces needed 30-50 years to catch up with the rest of the China [18].

The 13th five year plan outlines China's ambition to make Xinjiang become an important gateway to the West, Central and Southern Asia. It will play an important industrial hub for the supplies coming from South Asia and Middle East. The western province of Xinjiang can become an engine of growth by exporting machinery and finished goods to the South and Central Asian markets through the corridors and import much needed energy supplies and the raw material needed for its economic growth. Feedback on the first consignment of Sea food arriving from Indian Ocean to Xinjiang through CPEC reported that the goods were $10 \%$ cheaper than those brought from Eastern Coastal Cities of China [19].

\section{National Security Imperatives of CPEC for China}

While the OBOR may be purely an economic initiative, it will have far reaching effects on future geo-political landscape. The regions being covered by OBOR Initiative comprise nearly 70 percent of World's Energy Reserves and all the Muslim Countries [7]. The plan will impact US position abroad and Washington's response to the Initiative 
will shape the future course of US-China relations as well as the fate of global system.

CPEC is also an important segment of this grand Initiative. Gwadar Port which has been handed over to a Chinese company for a lease of forty years is located on the Gulf of Oman, just forty kilometers away from the Strait of Hurmuz, which is a trade route of one third of World's energy supplies. Some of the geo-strategic impacts of CPEC on Chinese National Security are appended in succeeding paragraphs.

\section{Security through development}

CPEC is important for the strategy of security through development in the context of China and some analysts named it as corridor of peace. China considers that improvements in security and economics are interrelated and development in one can complement the other [20]. China-Pakistan Economic Corridor can alleviate some of the domestic security concerns of China stemming from its predominantly Muslim province of Xinjiang in the western China. The province has witnessed some of the worst terrorist attacks on 'Chinese land. East Turkistan Islamic Movement (ETIM) which has sanctuaries in Afghanistan-Pakistan bordering regions is considered to be responsible for the terrorist activities in the mainland China. Analysts believe that the economic development and employment opportunities in the region would diminish the support for extremist ideologies in this region.

A rising country needs peaceful neighbors and the CPEC can be a harbinger of peace and prosperity to the backyard of China in the regions of Afghanistan and Pakistan (Af-Pak). China believes that the economic investment would bring internal stability to Pakistan [20]. The bordering belt of Af-Pak, which is believed to be the sanctuary for many proscribed militant organizations including ETIM, will be softened with increasing economic prospects in the region. By tackling jihadi organizations in neighboring Pakistan, China hopes to better secure its own territory. As the statistics released by a Pakistani newspaper suggest that CPEC would generate over 2 million jobs for the partnering countries [21]. Thus, CPEC represents China's international as well as domestic effort to deliver security through development.

\section{CPEC will provide energy security to China}

Energy security is emerging as a critical issue in Chinese National Security spectrum. At present, $90 \%$ of Chinese energy imports come through marine transportation channels. With increased industrialization, China's energy consumption profile is also increasing proportionally. As per the statistics from 2001-2010, annual energy consumption in China grew by $11.6 \%$ while at the same time, $2.8 \%$ was the global average [22]. China was a net exporter of Oil in 1990's and in 2015; China surpassed US to become World's biggest net oil importer with 7.4 billion barrels of crude oil per day [23]. China already achieved the milestone of World's largest petroleum products importer in 2013 and biggest energy consumer in 2011. China currently imports nearly 80 percent of its oil from Middle East and Africa through the Oceanic Channels, which pass through the contested regions of Malacca Strait and South China Sea. Energy source and route diversification has been the top priority for policy makers in Beijing. Malacca strait is considered a potential choke point for Chinese supply line and the CPEC provides an alternative land based route for the Energy supplies. Malacca dilemma further accentuates in wake of the US policy of pivot to Asia Pacific and its realignment with Japan, South Korea, Philippines, Vietnam and other South East Asian countries. Since China does not possess large scale substitutes to keep its transportation industry on road, therefore, shortage in transport fuel can paralyze the country and its economy by shutting down the vital means of transportation. Malacca strait can be a potential bottle neck for Chinese economic security due to the traditional as well nontraditional threats to the passage. Former arising from the hostile powers whereas the later emanating from piracy and terrorism [24]. Therefore, alternative routes of energy supply have vital place in the Chinese National Security calculus.

\section{Prospects of Regional Integration through CPEC}

China considers regional connectivity as the fundamental element and a necessary step in China's rise from a regional to global power. President $\mathrm{Xi}$, while addressing the foreign affairs committee of National People's Congress (NPC) in April 2014, said that "we will give priority to our neighbors in our diplomacy on all fronts" [25]. Previously Sino-US relations remained the top priority of Chinese foreign policy and China feared that improving relations with neighbors will inevitably cause conflicts in Sino-US relations [26]. Readjustment in Chinese Foreign Policy has come in a great way where improving relations with neighbors has been accorded priority even when it comes in conflicts with Sino-US relations. CPEC is a product of this regional integration and this project is likely to reduce Pakistan's dependence on US, thus reducing US influence in the region.

China believes that true powers will finally opt for regional integration and Japan lost the place of second largest economy in the World due to lack of appetite for regional integration[26]. Though CPEC is a bilateral agreement so far, but it was announced by Pakistani Premier that 52 countries have shown their interest to join the project including Iran, Afghanistan and Russia [27]. In a hopeful scenario, CPEC has the prospects to serve as a great East-West link via Pakistan connecting the Iran, India, Afghanistan and Central Asia to it [28]. Pakistan can be an economic hub for the markets of Central Asia, South Asia and Middle East, though; this aspect of CPEC faces multiple strategic challenges. If the opportunity is fully exploited, the whole region will be benefited and Indian qualms with China-Pakistan nexus will be eliminated. Indian reservations about the Chinese intentions will also be alleviated if India itself can be a partner for the project.

\section{Advancement of Chinese Neo-Mercantilism Strategy through CPEC}

Through OBOR Initiative, China has introduced a new strategy of cross-continental mercantilism. This neo-mercantilism is different than that of the 17th to early 20th century, when great powers used international mercantile as tool for advancing imperialism and colonization [29]. The neo-mercantilism through State Owned Enterprises (SOEs), China endorses the free trade and globalization while adopting a policy of non-interference in domestic affairs of the host nations. This neo-mercantilism aims at accumulation of wealth and capital for China through SOEs. CPEC being the stepping stone of this new strategy, China intends to set a new model of economic growth for the developing World through its SOEs. CPEC will be a testing lab for the strategy of neo-mercantilism on the foreign shores beginning a new era of Chinese leadership in the World economy and politics. 


\section{Securing Sea Lanes of Communications (SLOCs) in Indian Ocean Region (IOR)}

China has adopted a very cautious approach towards projecting its naval bases abroad as compared to its military and economic muscles. People's Liberation Army Navy (PLAN) does not have any overseas bases except a naval post in Djibouti for anti-piracy operations along with US, French and Japanese Naval Forces stationed there. A concept called "String of Pearls" was coined by an internal report of US Department of Defense in 2004 regarding Chinese potential intentions in IOR and building up of blue water navy likes United States [30]. The so called "String of Pearls" theory hypotheses that China aims to build a network of Sea Ports and naval facilities in the Indian Ocean protecting its SLOCs which starts from Chinese main land in the South China Sea and extends to the Port Sudan. The pearls along this string are considered to be Myanmar, Maldives, Bangladesh, Srilanka and Pakistan in IOR, where China would build commercial ports and shipping facilities.

Japan, India and USA have been actively engaging in maritime security operations in the Indian Ocean Region (IOR) securing vital Sea Lanes of Communication (SLOCs). After 9/11, Japan formally authorized Japanese Self Defense Forces to dispatch warships to the Indian Ocean [22]. India has also built its overseas naval base in the Adman and Nicobar Islands and the US is a leading player in conducting anti-piracy operations and keeping international trade safe in high seas. China has been the World's biggest maritime trader for quite some time without contributing much to the security of international maritime trade. According to the statistics released by Australian Trade and Investment Commission for the year 2014, Chinese imports and exports were World's highest at US $\$ 4.3$ trillion and the second place was claimed by the US with $\$ 4.0$ trillion dollars of trade [31]. USA and China contribute nearly $25 \%$ of the World's trade and over $90 \%$ of global trade is carried out through sea.

China must be well prepared to secure Sea Lanes of Communications (SLOCs) in IOR from traditional as well as nontraditional threats. Gwadar Port, located just 250 Kilometers away from strait of Hurmuz, can serve as an ideal platform for Chinese naval forces in keeping international trading lanes open. A US retired admiral remarked that, before too long, $85 \%$ of the oil tankers leaving strait of Hurmuz will turn left towards Asia and it's a matter of time when USA will decide that protection of Chinese oil imports as a waste of American taxpayer's money [32]. China has started engaging in anti-piracy operations since 2008 in collaboration with other regional and international forces. Gwadar port and Pakistani naval forces can play an important role along with other littoral states of Indian Ocean in keeping international trade safe in high seas. The free ride which China has enjoyed so far may not be workable for long and the port facilities developed under the OBOR Initiative will be very important in projecting People's Liberation Army Navy (PLAN) assets abroad.

\section{Impact on China's Neighboring Diplomacy with India}

India has been skeptical about OBOR Initiative and her response to each segment of the initiative has varied from a cautious welcome to an opposition. During the President Xi's visit to India in Sep 2014, the joint declaration mentioned about cooperation on BCIM Economic Corridor, skillfully missing the name of OBOR Initiative [33]. China seeks Indian cooperation on 21st Century Maritime Silk Road, but, Indian response has remained lack lustering. The clearest response of India on OBOR Initiative has come out on CPEC, to which it has opposed, terming it to be passing through Pakistani held Kashmir which India claims to be its own. CPEC is a big challenge to China's neighborhood diplomacy of amity, sincerity, mutual benefit, and inclusiveness in relations with India [34]. China-Pakistan need to subside Indian fears about the project in order to avoid fueling a proxy tussle in the restive province of Baluchistan in southern Pakistan, which is critical for the success of CPEC. In relation to the OBOR Initiative, Chinese objective would be to win Indian cooperation or at least a neutral stance. But, given the clash of interest on many aspects of OBOR Initiative, Indian response is likely to evolve from a "no stance" to an "active opposition" through covert and overt means.

\section{Conclusion}

The OBOR Initiative is a grand global strategy of economic development which has no parallels in human history and CPEC being the leading project under the scheme has its own significance. A detailed discussion of perceived Chinese objectives from the Initiative have been carried out in this paper, yet, the degree of success in achieving these objectives is not ascertained. The rate of success in CPEC will determine the future course of OBOR Initiative and set an era of Chinese dominance in international affairs. The accomplishment of CPEC will establish a new model of international development led by Chinese investment. CPEC will bring the coast of Indian Ocean to Chinese sphere of influence and will open up new avenues for internationalization of Renminbi, making it a competitor if not replacement of the US dollar in international market. The project would consume some of the Chinese excess capital in outward foreign direct investment providing multibillion dollar business opportunities to the Chinese state owned enterprises in energy, transportation and construction sectors. CPEC will also testify the new model of economic development and prove to be a catalyst in keeping the Chinese "new normal" economic growth on a steady upward pattern.

CPEC is a course of mutual benefits and another milestone of strategic partnership between China and Pakistan. Though, there are some serious governance and security challenges in Pakistan deterring the project to achieve its full potential. Challenges to CPEC in Pakistan and the rate of success in outlined Chinese ambitions may be an interesting research direction for the future studies, when the projects are unfolded to the ground realities in Pakistan. The competing powers in the region and beyond may consider it a zero sum game and try to impede or disrupt the project. China-Pakistan friendship is time tested, therefore, the partner countries presume to overcome the challenges and achieve the mutual interests associated with the project.

\section{References}

1. Capital G (2015) The potential of one belt, one road. The Global Capital.

2. Ali A (2016) China Pakistan Economic Corridor : Prospects and Challenges for Regional Integration. Arts and Social Sci Journal.

3. Pakistan Government (2017) China Pakistan Economic Corridor.

4. Bhattacharje DD (2015) China Pakistan Economic Corridor (CPEC) issue brief. Indian Council of World Affairs, pp: 1-15.

5. Siddique S (2017) CPEC investment pushed from $\$ 55 \mathrm{~b}$ to $\$ 62 \mathrm{~b}$. The Express Tribune, Islamabad.

6. Erebus Wong LKC, Tsui S, Tiejun W (2017) One belt, one road: China's strategy for a new global financial order. Monthly Review Foundation, New York.

7. Luft G (2016) It takes a road. Institute Analysis, Institute for the Analysis of Global Security, USA. 
Citation: Rahman SU, Shurong Z (2017) Analysis of Chinese Economic and National Security Interests in China-Pakistan Economic Corridor (CPEC) under the Framework of One Belt One Road (OBOR) Initiative. Arts Social Sci J 8: 284. doi:10.4172/2151-6200.1000284

Page 7 of 7

8. Mantraya (2016) One belt, one road, one Singapore-analysis. The Eurasia Review.

9. Bank W (2017) China Overview.

10. Joe Barnes AB (2015) Rethinking US strategy in the Middle East, Report Baker Institute for Public Policy and the Center for the National Interest.

11. Patton M (2016) US dependence on foreign oil hits 30-year low. Forbes.

12. Workman D (2017) Crude oil imports by country. World's Top Exports.

13. Faheemullah Shaikh QJ, Fan Y (2016) Prospects of Pakistan-China energy and economic corridor. Renewable and Sustainable Energy Reviews 59: 253-263.

14. Berger R (2016) Over capacity in China, E.C.o.C.i. China. EU Chamber of Commerce in China, p: 54.

15. Fan R (2015) China's excess capacity: drivers and implications. Law Offices of Stewart and Stewart.

16. Jamal N (2016) Competition for local steel. Daily Dawn.

17. Danese P (2015) Belt and road enterprises conflicted about RMB Prospects. The Global Capital.

18. Ferdinand $\mathrm{P}$ (2016) Westward ho-the China dream and 'one belt, one road: Chinese foreign policy under Xi Jinping. International Affairs 92: 941-957.

19. Jingjing M (2017) China-Pakistan economic corridor aims to boost trade between two countries. The Global Times.

20. Shi Zhiqin LY (2016) The benefits and risks of the China Pakistan Economic Corridor. The Carnegie-Tsinghua Center for Global Policy.

21. Reuters (2017) CPEC to generate 2.32 million jobs within next two years. The Nation, Islamabad.

22. Wang L (2015) Sea lanes and Chinese National Energy Security.Journal of Coastal Research.

23. Gloystein JGP (2015) China becomes world's top crude buyer despite economy stuttering. Reuters.
24. Marantidou V (2014) Revisiting China's 'String of Pearls' strategy: places 'with Chinese characteristics' and their security implications. Issues and Insights.

25. Ramay SA (2016) CPEC: A Chinese dream being materialized through Pakistan. Sustainable Development Policy Institute, Pakistan.

26. Xuetong Y (2014) Silk road economic belt shows China's new strategic direction: Promoting integration with its neighbors. The CarnegieTsingua Center for Global Policy.

27. Desk N (2017) 52 Countries interested in CPEC: Nawaz. Pakistan Observer.

28. Strasser F (2016) China-Pakistan economic corridor: A Road to Peace. USIP.

29. Zhang J (2016) What's driving China's one belt, one road initiative?. East Asia Forum: Eonomics, Politics and Public Policy in East Asia and the Pacific.

30. MacDonald JA (2004) Energy futures in Asia: final report. Booz-Allen and Hamilton.

31. Thirlwell M (2015) The world's leading trading nations.

32. Willasey T (2016) Gwadar and 'The String of Pearls'. The Gateway House.

33. Haixiao S (2016) China's belt and road initiative and its Neighboring diplomacy, Chapter 6, The Belt and Road Initiative: India's strategy and its effects. India Study Center, Guandong Institute for International Strategies, China, pp: 109-123.

34. Piao Zhuhua LX, Zhuoyou T (2016) China's Belt and Road Initiative and its neighboring diplomacy, Chapter 11, The Political Risk Analysis on China's Direct Investment Environment of the Belt and Road Initiative. India Study Center, Guandong Institute for International Strategies: China, pp: 223-248. 